\title{
General dentist orthodontic practice in foreign legal systems
}

Ivan Toshio Maruo', Armando Saga ${ }^{2}$, Maria da Glória Colucci ${ }^{3}$, Orlando Tanaka ${ }^{4}$, Hiroshi Maruo ${ }^{4}$

Objective: General dentist orthodontic practice is a controversial issue and this paper aims to analyze it comparing foreign laws to Brazilian Legal System.

Methods: Regulations and scientific texts concerning orthodontic practice by general dentists, in Portuguese or English language, were sought.

Results and Conclusion: Portugal clearly forbids general dentist orthodontic practice; United States of America do not clearly forbid general dentist orthodontic practice, but do regulate and promote campaigns to encourage public to seek specialist service; in Australia and England, corrective orthodontics are offered both by orthodontists and general dentists; it was not possible to evaluate how orthodontic services are provided in Eastern Europe; and the fact that general dentists are forbidden to practice corrective orthodontics in Brazilian Legal System is compatible to other countries policy.

Keywords: Orthodontics. Graduation course. General dentist. Legality. Foreign laws.

${ }^{1}$ MSc and PhD in Orthodontics, Pontifical Catholic University of Paraná (PUCPR).

${ }^{2}$ Professor, Specialization in Orthodontics, Brazilian Association of Orthodontics Paraná Section (ABO-PR).

${ }^{3}$ Head Professor, Curitiba Law School, Faculdades Integradas Curitiba (FIC). Adjunct Professor, Law School, Federal University of Paraná (UFPR). Counselor of Biolaw and Bioethics Group, Faculdade Integradas Curitiba (FIC).

${ }^{4}$ Head Professor of Orthodontics. Pontifical Catholic University of Paraná (PUCPR).
How to cite this article: Maruo IT, Saga A, Colucci MG, Tanaka O, Maruo H. General dentist orthodontic practice in foreign legal systems. Dental Press J Orthod. 2012 Mar-Apr;17(2):62-8.

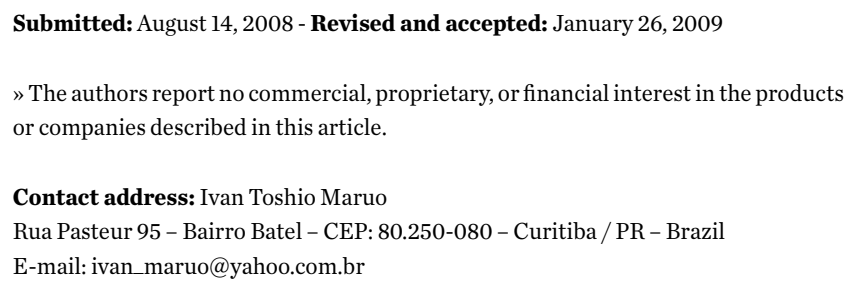

Contact address: Ivan Toshio Maruo

Rua Pasteur 95 - Bairro Batel - CEP: 80.250-080 - Curitiba / PR - Brazil

E-mail: ivan_maruo@yahoo.com.br 


\section{INTRODUCTION}

History reports that the first dental surgeon focusing his clinical practice in orthodontics was Edward $\mathrm{H}$. Angle, in $1887,{ }^{8}$ and that orthodontics was only regulated as an Dental specialty, by the efforts of Charles H. Tweed, in 1929, who became the first specialist in orthodontics. ${ }^{27}$ From this establishment as a specialty, orthodontics started to spread around the world absorbing peculiarities in each country.

In the Brazilian legal system there is a conflict between the principle of legality (permissive) and the principle of human being dignity (impeditive) as regards to the professional practice of orthodontics by the non-specialist dental surgeon. ${ }^{19}$ This is a polemic issue involving, basically, legal interpretation. To solve this issue it is adequate to use the Science of Law that according to Gusmão, ${ }^{15}$ is a methodically coordinated knowledge resulting from the ordered study of legal standards aiming to understand the objective meaning of these legal standards and to build the law system, as well to discover its historical and social roots.

Maruo et $\mathrm{al}^{19}$ analyzed this issue by means of the legislation and of the legal decisions of Brazilian courts, and they concluded that using the Theory of Legal Argumentation, ${ }^{12}$ the practice of a non-specialist dental surgeon is limited only to preventive and interceptive orthodontics.

However, because of the importance of this subject, the professional practice of orthodontics by a non-specialist dental surgeon must be analyzed through other available tools in the Science of Law, in such a way that it can bring peace to the community, to dental surgeons in general and to orthodontists. One of such tools frequently used by the Law practitioners is the Comparative Jurisprudence.

Ancel $^{7}$ states that yet in ancient Greece, Lycurgus in Sparta and Solon in Athens traveled the known world in order to meet legal institutions from other places before creating their own laws. Now for Contemporary Law, Comparative Jurisprudence started following the path of other comparative sciences like comparative anatomy, and its objective was to find in the legal field an equivalent of the organs in anatomy, i.e., similar bodies playing similar functions. ${ }^{16}$

Coutinho $^{11}$ supports its importance because
Comparative Jurisprudence is based on the comparison and confrontation between different legal models, which is of uttermost importance to the questioning, to put in check some rule, institute, ordinance or legal interpretation. Comparison in most cases involves the act of questioning, of putting in doubt, of taking out the absolute certainty. ${ }^{11}$ From this, one can reach a new model, a solution to solve and attend social conflicts. ${ }^{11}$

In this context, the aim of this paper is to analyze the issue of professional practice of orthodontics by non-specialist dental surgeon in Comparative Jurisprudence, to verify if it is or not in accordance to the Brazilian law.

\section{MATERIAL AND METHODS}

To carry out this research, a search was performed in the bibliographic and legal writings in portuguese and english languages concerning the practice of orthodontics by non-specialist dentists.

The results were organized and divided according to each country to make its interpretation and comparison easier to the Brazilian law.

\section{RESULTS}

\section{United States of America (USA)}

Orthodontics as a specialty and science originated in the USA by the efforts of Angle. ${ }^{8}$ The USA are known for adopting the legal system of Common Law (the custom is the main source and the laws itself are secondary sources) and the capitalist system of free market. ${ }^{15}$

In that country, orthodontics is regulated by the Federal Government in general and more specifically by the Disease Control Centers (DCC); by every State governments - main regulator of the profession - by the Regional Council of Dentistry or state regulatory agency of many health professions which determine the necessary qualifications for practicing orthodontics inside the state, and by professional organizations, like the American Dentistry Association (ADA) and state dentistry associations with their ethical codes and the quality standards acceptable inside the community. ${ }^{26}$

Besides these regulations, some American states create State Licensing Councils to safeguard the public. ${ }^{26}$ These agencies are formed by a group of citizens and usually have authority to: 1) Establish necessary 
specific qualifications for initial license; 2) Make examinations and grant license for qualified candidates; 3) Establish more specific practice and conduct standards; 4) Take disciplinary decisions against those acting inappropriately; and 5) enact rules in order to perform their obligations. ${ }^{26}$

In these norms there is no practical objection against the practice of orthodontics by general practitioners, so that researches like the ones of Wolsky and McNamara $\mathrm{Jr}^{29}$ and Galbreath et al ${ }^{14}$ show that this occurs very frequently.

Nevertheless, several actions are taken by Orthodontic professional associations to stimulate the population to look for a specialized service like the case of American Board of Orthodontics (ABO), founded in 1929, and its campaign to inform people on the reasons for searching a specialist started in May 2006.

\subsection{American Board of Orthodontics}

The ABO was founded in 1929 by seven important orthodontists under the orientation of Dr. Albert $\mathrm{H}$. Ketcham, who is today the name of the most important award of the Board. ${ }^{9}$ To understand their intentions we just need to consider Dr. Ketcham's own words in a letter to Dr. B. F. Dewel: ${ }^{9}$

"We must keep in mind that the object of the Board is to elevate the practice of orthodontia. We should not make our requirements for examinations so high that the average orthodontist may not aspire to perfect himself so that he may pass the Board's examination. We must remember that our function is different from that of the faculty of an orthodontic school, which gives examinations to students who have all received the same lecture courses and techniques. We must adapt our examinations to the applicant; try to discover if he is safe, whether he has the technical skill and scientific knowledge, coupled with good common sense, good personality, and honesty of purpose, to ensure that he is a good moral risk."

The ABO has been uninterruptedly certifying orthodontists since 1929, with the exception of a period of seven years during the World War II, submitting applicants to various evaluation criteria: Written research and presentation of clinical cases until 1963; as from 1963, the option for research or by written evaluation, besides the presentation of clinical cases; as from 1978 the option for research was excluded and the written evaluation along with presentation of clinical cases was defined. All candidates for $\mathrm{ABO}$ should be orthodontists following the standards defined by ADA and by AAO. ${ }^{9}$

In 1960, the AAO and the ABO produced a document for the Conference of National Organizations for practice areas of dentistry, requested by the ADA, clarifying americans about the $\mathrm{ABO}$ and the specialty of orthodontics. In this document the goals of ABO were made clear, which are: 1) Stimulate and keep alive the research spirit and the continuous improvement between students and practitioners of orthodontics; 2) establish the competence of the orthodontics experts; and 3) organize, control and conduct exams aiming to evaluate orthodontists skills and grant certificates for those inside the demanded standards of the ABO. ${ }^{1}$

It is from this very same document that Americans draw the characteristics of their orthodontics. Orthodontics specialty and the AAO have the objective to: 1) Promote advances in orthodontics science and art; 2) encourage and support research; 3) struggle for high excellence standards in education and orthodontics practice; and 4) give its contribution to health. ${ }^{1}$

In the undergraduate course the objectives of orthodontics is to allow the formation of a general clinician able to: 1) Anticipate and detect a malocclusion; 2) Make decisions to prevent malocclusion as always as possible; 3 ) Use this knowledge as a tool in all other levels of Dental practice; and 4) Understand the possibilities of orthodontic treatment. ${ }^{1}$

For this end, the following subjects are essential: ${ }^{1}$

1) A term definition: Concept, diagnosis and discipline. Preventive, interceptive and corrective orthodontics. What orthodontics student should know regarding this;

2) Growth and development - from a preventive point of view;

3) Physiology of the stomatognathic system;

4) Incidence and acknowledgment of malocclusion;

5) Etiology of malocclusion;

6) Diagnostic elements and its interpretation importance of case analyses to determine preventive, interceptive and corrective conducts; 
7) Undesirable sequels of malocclusion;

8) Biomechanical principles of dental movement; tissue response to orthodontics;

9) General principles of orthodontic therapy - description of appliances in use and understanding of treatment methods;

10) Preventive dentistry - The maintenance of normal occlusion;

11) Interceptive orthodontics;

12) Corrective orthodontics - limited to some moderated cases of anterior crossbite, single tooth posterior crossbite, deep bite and functional problems; space control with removable appliances and small fixed appliances, together with restorative dentistry and periodontics; and understanding of advantages and disadvantages of corrective procedures."

Towards orthodontics specialty, $\mathrm{AAO}$ and $\mathrm{ABO}^{1}$ understand:

"Orthodontics considers its major responsibility the supervision of growth and development of the dentition and facial structures associated with maturity and eruption of teeth. Prevention of malocclusion is the major objective of orthodontics. This specialty welcomes the assistance in space maintenance, teeth preservation and correction of habits by the general practitioner and other specialties, but all corrective procedures involving tooth movement requiring functional or mechanical treatment are duties of the orthodontist. These are traditional practice areas of orthodontics along the specialty history."

In this way, the AAO's given suggestion is that graduate courses in orthodontics should be planned with a total of 2985 hours, as follows: ${ }^{1}$

"1) 1035 of basic subjects - Head and neck anatomy, Teeth applied histopathology and support structures; Growth and development; Oral physiology; Oral and cephalometric radiology; Orthodontic materials; Embryology and Human genetics; Biomechanical principles; Treatment and Case analysis; scientific methodology; research; seminars in general.

2) 150 hours of related matters - Speech therapy; Child psychology; Management; Bacteriology of dental caries; Comparative anthropology and anatomy; Congenital facial deformities; oratory; preparation of scientific research; and Dental education.

3) 1800 hours of clinical and laboratory practice."

For evaluating clinical cases, an index was developed. ${ }^{10}$ For each criterion the case loses a specified amount of points, and, at the end if a case has lost more than 30 points, the applicant for certification does not pass; if he has lost less than 20 points, the applicant is approved. ${ }^{10}$

Today the ABO certification process is available for orthodontists already practicing the specialty as well as for newly graduated professionals, a re-certification is necessary every 10 years..$^{22}$ In phase I, the applicant's curriculum is examined, i.e., if there is a graduate education in orthodontics in the standards demanded by the ADA and the AAO; in phase II a written exam is performed; and, in phase III, the applicant must present 10 cases with initial characteristics required by the $\mathrm{ABO}$ for evaluation; for re-certification, the applicant has to present an amount of new treated cases. ${ }^{22}$

\subsection{The campaign for public information}

Since it was demonstrated that orthodontics is currently practiced by the general practitioner, the AAO started a research in 2005 to develop an advertising campaign to inform the public on reasons to look for a specialist in orthodontics. ${ }^{2}$

This research was performed by a company specialized in marketing campaigns and, it initially realized that the public has doubts on the difference between orthodontic treatment conducted by an orthodontics specialist and by other professionals in dentistry. ${ }^{2}$ With these data, the company developed a radio, television, press media and internet campaign and tried it with a selected public. The most effective message was the one focusing that orthodontics specialists have 2 or 3 more additional years of training than general practice dentists, and along this course, they are oriented by specialized professors. ${ }^{2}$

This advertising proposal was initially discussed in the AAO Annual Congress in Las Vegas, from May 5 to 9, 2006. After approved, the campaign "More than a Smile" was launched and started being propagated on television, magazines and internet. ${ }^{3}$

The answer of the public was promising, with many consultations in the AAO's homepage about who were the specialists in orthodontics. ${ }^{4,5,6}$ 


\section{EUROPE}

The European countries can be treated in a single topic, since they essentially followed the teaching of Pierre Fauchard and, later, of Angle. ${ }^{25}$

\subsection{Portugal}

The law regulating dentistry in Portugal is law $\mathrm{n}^{\circ} 40$ of 22 August, 2003. In its Article 2 it determines the scope of this law, determining the characteristics of the dental surgeon:

"Article 2

Field of application

1 - Dental Surgeons are the professionals identified in official listings published in official Journal, series 2, number 270, of 22 November, 2002.

2 - The activity of dentistry depends on the possession of dentistry certificate and respective professional portfolio.

3 - The profession of dentistry is residual, it is hereby expressly forbidden any measures aimed at the settlement of future work situations."

And, as regards to orthodontics, it forbids its practice by general clinicians in article 3 :

"Article 3

Framework of dental activity

1 - Dentists can execute the following professional actions:

a) Dentistry;

b) Prosthesis;

c) Endodontics;

d) Tooth extraction of erupted teeth and roots are not included;

e) Treatment of dental calculus and polishing;

f) Dental radiology, so long as facilities respect current legislation.

2 - All practices not referred above are expressly prohibited from the scope of activity of dentists, including:

a) The procedures in the field of dental implant surgery;

b) Procedures of fixed or removable orthodontics;

c) All surgical procedures not listed in subparagraph d) above;

d) Procedures in the field of endodontic surgery;

e) The total rehabilitation with fixed prosthesis. Except in situations of Article 4:
"Article 4

Special arrangement

1 - Exceptionally, dentists can practice orthodontic procedures inasmuch as meeting the following terms:

a) Hold a valid licence for dentistry practice issued by the competent authorities prior the accession of Portugal to the European Communities;

b) Have at least 500 hours of specific formation in orthodontics, proven by documents;

c) Be approved in orthodontics examination carried out by the Ethic and Professional Council of Dentistry.

2 - There will be a single exceptional process to verify requirements of previous number, in time and conditions defined by the Ethical and Professional Council of Dentistry.”

\subsection{England}

In England the practice of orthodontics occurs both for specialists and general practitioners, and according to a study by Fox et al, ${ }^{13}$ two regions in England were analyzed concerning differences in demand and treatment results. Evaluating models before and after orthodontic treatment, results show that regardless of region, the higher were the orthodontic education, better were the results achieved.

\section{Eastern Europe}

In Eastern Europe countries, dental service has changed after the fall of the Berlin wall, in 1989, and the fall of communism in the former Soviet Union in $1991 .^{28}$ Before dental practice was performed by stomatologist doctors, now private practice by dental surgeons have been increasing gradually. ${ }^{28}$ Countries as the Czech Republic, Hungary and Poland offer private health services not including fixed orthodontic treatment, which shows the importance given to this specialty. ${ }^{28}$ Available references do not allow to affirm if non-specialist dental surgeons can practice orthodontics.

\section{Australia}

In Australia, the practice of orthodontics is not legally limited to the specialist orthodontist as noted in some researches. ${ }^{17,18}$ Anyway, it was noted that even with a decrease of periodontal diseases and caries, most part of the non-specialist dental 
surgeons dedicate only $2.5 \%$ of time to orthodontic procedures and only $4.3 \%$ to their patients. ${ }^{17} \mathrm{Be}-$ sides that, it can be seen that the amount of orthodontic procedures performed was proportional to the hours of training in orthodontics in the undergraduate courses in dentistry. ${ }^{18}$

\section{DISCUSSION}

Portugal influenced Dental practice in Brazil while it still was a Portuguese colony. ${ }^{23}$ The Portuguese State, according to article 4 of Law $\mathrm{n}^{\circ} 40$ of august 22 , 2003 , specifically prohibits the practice of orthodontics with fixed or removable appliances by the nonspecialist dental surgeon.

Likewise, the USA - where a large part of scientific production in orthodontics is originated -, even though it does not specifically prohibit the professional practice of orthodontics by general practitioners, it adopts others ways to control this practice. A specific prohibition in the USA is unnecessary because the country adopts the Common Law, ${ }^{15}$ i.e., gives privileges to the current customs over very extensive and detailed law texts.

From a technical point of view, by directions given since 1960 by the $\mathrm{AAO}$ and the $\mathrm{ABO},{ }^{1}$ it is possible to observe that the USA is stricter than Brazil in both undergraduate and graduate orthodontic education. Furthermore, the campaign of the AAO to inform people since $2006^{3}$ with real results, ${ }^{4,5,6}$ shows how it is possible to influence patients to look up for specialists in orthodontics to perform orthodontic treatments, without the need of laws with this purpose.

It was not possible to conclude if in eastern European countries there is permission for non-specialists to practice corrective orthodontics. Nevertheless, results in Portugal and England demonstrate that orthodontists offered better quality of treatment in comparison with general practitioners, ${ }^{13}$ which suggests a similar tendency in the whole European Community in a larger or smaller degree.

Only in Australia the practice of orthodontics seems to be stimulated to non-specialist dental surgeons. ${ }^{17,18}$ This fact is perfectly acceptable, since Australia is a fairly new country in need of manpower to all areas.
The professional practice of corrective orthodontics by a non-specialist dental surgeon is polemic in the Brazilian Legal System. ${ }^{19}$ Using Comparative Jurisprudence, we can understand that the corrective orthodontics practice prohibition that exists after analyzing the Brazilian Legal System, also exists in other countries. Since the value of comparative jurisprudence relies in the interpretation of legal normatives, ${ }^{11}$ this paper agrees with the work of Maruo et $\mathrm{al}^{19}$ that after analyzing the legislation and decisions of Brazilian courts, it concluded that the non-specialist dental surgeon can not practice corrective dentistry.

Thus, it is valid to remember that the media, ${ }^{24}$ back in 1995, gave alert about the increasing number of victims of orthodontic treatments by non-specialist professionals. Orthodontics is directly related to human health. ${ }^{21}$ Damages caused by a badly conducted orthodontic treatment are a violation of the body of the patient and also means a damage to his psychophysical integrity, which is a part of human dignity. ${ }^{20}$ Human dignity also is a principle protected by the first article, clause III of the Brazilian Federal Constitution.

\section{CONCLUSIONS}

Using Comparative Jurisprudence we can conclude that:

1) Portugal completely prohibits the professional practice of corrective orthodontics by a nonspecialist dentists;

2) The USA does not prohibit the professional practice of corrective orthodontics by a nonspecialist dentist, but creates policies and campaigns to stimulate people to look for a specialist.

3) In Australia and England corrective orthodontics is practiced both by orthodontists and nonspecialists dentists;

4) It was not possible to evaluate the legislation in Eastern Europe towards this subject; and

5) The prohibition of corrective Orthodontic professional practice by non-specialist dentists in the brazilian Legal System is consistent with what is happening in countries around the world. 


\section{REFERENCES}

1. American Association of Orthodontists. Specialty practice in dentistry. Am J Orthod. 1960;46(8):588-94.

2. Council on Communications (COC): your advertising has been a success. NESO News. 2008;118:9.

3. American Association of Orthodontists. 'More than a smile' consumer awareness campaign has officially launched. Bulletin. 2006;24(6):1.

4. American Association of Orthodontists. Consumers eagerly respond to 'More than a smile' consumer awareness campaign. Bulletin. 2006;24(7):3.

5. American Association of Orthodontists. Latest initiatives for the AAO's consumer awareness campaign are under way. Bulletin. 2007;25(5):16.

6. American Association of Orthodontists. 'More than a smile' campaign drives traffic to AAO's public Web site. Bulletin. 2007;25(6):3.

7. Ancel M. Utilidade e métodos do direito comparado (Elementos de introdução geral ao estudo comparado dos direitos). 1a ed. Porto Alegre: Ed. Sérgio Antônio Fabris; 1980.

8. Asbell MB. A brief history of orthodontics. Am J Orthod Dentofacial Orthop. 1990;98(2):176-83

9. Cangialosi TJ, Riolo ML, Owens SE Jr, Dykhouse VJ, Moffitt AH, Grubb JE, et al. The ABO's 75th anniversary: a retrospective glance at progress in the last quarter century. Am J Orthod Dentofacial Orthop. 2004;125(3):279-83.

10. Casko JS, Vaden JL, Kokich VG, Damone J, Don James R, Cangialosi TJ, et al. Objective grading system for dental casts and panoramic radiographs. Am J Orthod Dentofacial Orthop. 1998;114(5):589-99.

11. Coutinho ALC. Direito comparado e globalização. Prima Facie. 2003;2(2):30-41.

12. Cristóvam JSS. A resolução de colisões entre princípios constitucionais. Jus Navigandi. 2003 [cited in 2007 Dec 28];7(62). Available from: http://jus2.uol. com.br/doutrina/texto.asp?id=3682

13. Fox NA, Richmond S, Wright JL, Daniels CP. Factors affecting the outcome of orthodontic treatment within the general dental service. J Orthod. 1997;24(3):217-21.

14. Galbreath RN, Hilgers KK, Silveira AM, Scheetz JP. Orthodontic treatment provided by the general dentist who have achieved Master's level in the Academy of General Dentistry. Am J Orthod Dentofacial Orthop. 2006;129(5):678-86.

15. Gusmão PD. Introdução ao estudo do Direito. 23ạ ed. Rio de Janeiro: Forense; 1998.
16. Gutterridge HC. El Derecho comparado: introducción al método comparativo en la investigación y en el estudio del derecho. 1a ed. Barcelona: Artes Gráficas Rafael Salvá; 1954.

17. Lawrence AJ, Wright FAC, D'Adamo SP. The provision of orthodontic services by general dental practitioners. 1. Methods and descriptive results. Aust Dent J. 1995;40(5):296-300

18. Lawrence AJ, Wright FAC, D'Adamo SP. The provision of orthodontic services by general dental practitioners. 2. Factors influencing variation in service provision. Aust Dent J. 1995;40(6):360-4.

19. Maruo IT, Colucci MG, Maruo H, Tanaka O, Camargo ES, Vieira S. Estudo da legalidade do exercício profissional da Ortodontia por cirurgião-dentista nãoespecialista. Rev Dental Press Ortod Ortop Facial. 2008:14(6):42e1-10.

20. Moraes MCB. Danos à pessoa humana. 1a ed. Rio de Janeiro: Renovar; 2003.

21. Rinchuse DJ, Rinchuse DJ. Orthodontics justified as a profession. Am J Orthod Dentofacial Orthop. 2002;121(1):93-6.

22. Riolo ML, Owens SE Jr, Dykhouse VJ, Moffitt AH, Grubb JE, Greco PM, et al. A change in the certification process by the American Board of Orthodontics. Am J Orthod Dentofacial Orthop. 2005;127(3):278-81.

23. Samico A. CRO-PE: Institucional - histórico; 1992. Disponível em: http://www.crope.org.br/hist-pg05.html. Acesso em: 20 fev. 2008.

24. Saúde. Sorrisos amarelos. VEJA. 1995;28(2):55

25. Schmuth GPF. História da Ortodontia na Europa. In: Interlandi S. Ortodontia: bases para iniciação. 4a ed. São Paulo: Artes Médicas; 1999. p. 19-27.

26. Troolin P. State regulation of the practice of dentistry. Semin Orthod. 1997;3(2):133-8

27. Vaden JL, Dale JG, Klontz HA. The Tweed-Merrifield edgewise appliance: philosophy, diagnosis, and treatment. In: Graber TM, Vanarsdall RL Jr. Orthodontics: current principles and techniques. 2nd ed. Saint Louis: Mosby; 1994. p. 627-84.

28. Widström E, Eaton KA, Borutta A, Zybizbánska E, Broukal Z. Oral healthcare in transition in Eastern Europe. Br Dent J. 2001;190(11):580-4.

29. Wolsky SL, McNamara JA Jr. Orthodontic service provided by the general dentists. Am J Orthod Dentofacial Orthop. 1996;110(2):211-7. 